\section{SING A SONG OF SEASONS}

\section{ELIZABETH CRUICKSHANG, Regina}

And as we sing we remember the gems in the melody.

Last winter when the air held brilliance by day and the stars by night, we dreamed of "ferns and soft green mosses, and small wild feet tiptoeing down a hill." Then the Gates of Eden swung wide!

In April two fox sparrows, rufous tails flashing, rested a day in our yard.

Do we ever hear bird song without the heart being lightened? It is not so much the song always, but the associations conjured up. How intense were the impressions on the screen of the soul when we lived without worry!-filtered sunshine under leafy trees-apple orchardslambs on green hillsides. We know distance lends enchantment to the view, but how often we seek the quiet places just to remember.

In the summer we made our first acquaintance ' with Black Henbane and wondered if a skunk had got in the car!

And Dragon flies-some evenings the air itself was quivering over the prairie with hovering dragons, slim shimmering sapphire ones, bronze ones, gilded green ones, polished crimson ones and fragile colourless ones, all elegant wee creatures.

Then in no time at all the "gay scenes of summer were over and millions of warblers had fled in the train of the sun-seeking swallows."

Restless Snow Buntings appeared like silver ornaments, misplaced in sunny stubble fields, one moves, all follow.

By the river bed, where waters murmured tranquilly in spring, we spied a shelf fungi under a dead stump. Judy climbed easily but wee Nancy needed help. We lost our footing and sliding down the bank disturbed a porcupine. Fogarty suffered only one quill, but we had a fine view of the large mushroom, beautiful in its copper, coffee and buff tones.

Juncos were flocking in the ravine. Their twittering among the as- pens, gold-brown spotted-here was lyric poetry visible.

David Grayson says "Everyone is a magnet highly and singularly sensitized. Some draw to them fields and woods and hills and are drawn in return."

Oh, sing a song of seasons-the magnet's pull is felt in all of them.

\section{BEAUTY IS ALWAYS PRESENT}

By RAY PETERSON

R.R. 2, Tofield, Alberta

"And the third snow is winter," an old maxim expounds. Perhaps, the nature prophet who theorized thus could not see the year 1953 in his crystal ball. Our third offering of snow this fall has come and nearly left us in the lingering warmth of a long Indian summer.

Yesterday morning was highlighted by a walk about the farm. The countryside was a pleasant landscape of browns, greys, and weathered yellows, with snow-powdered hollows and ice-silvered ponds. The air seemed exceptionally sweet and fresh, braced with the tang of an early fog.

A great flock of ducks, roused from nearby Hastings Lake, swept high over the poplar woods. Quack! Quack! The sound of the southbound ducks touched a poignant note.

From the safety of a willow thicket, a dapper villain of the bird world swore derisively. As I drew nearer, however, the magpie's usual caution replaced its harsh boldness. In a graceful display of sleek, black and white lines, it retreated to a more discreet distance.

Our collie suddenly bounded away from me and dashed excitedly across a meadow. Rather curiously, I followed him to where he was stirring up a great uproar in a heavy stand of trees. I didn't need to follow his pointing nose. An indignant squirrel shouted for attention as he chir-r-red loudly from the tip of a rather isolated sapling. Close by, on a large, dead poplar, its companion, as though ignoring the din, was curled in a contented-looking ball of fur. I was pleased to see the little ani(Continued on Page 30) 